\title{
Dreaming Poetry in American
}

Poems are meeting on the corner of somewhere and somewhere, where mom sounds like an address you'd write to and words have girlfriends or notes attached, clever like string, they fly close to the sun on Icarus wings warm and dangerous-

there are no bad trapeze artists if you believe in Darwin, so it is with poetry it's just the packaging, sentiment can be convenient it's not a crime, it's a way to keep children and blush and stumble then let them go, it's first things and last things which may be metaphors but mostly it's just first things and last things, a way to lengthen the dark, or the way finding a piece of popcorn down the back of your couch can inspire 80 kilograms of popcorn to form a mountain in a gallery I wouldn't say piece, but kernel, yet how far removed is corn from the pop of it. 